\section{Fatal Lactic Acidosis after an Overdose of Phenformin}

\section{Brit. med.F., 1967, 4, 216}

A number of papers have been published concerning the dangers encountered in the use of the diguanide phenformin as an oral hypoglycaemic agent (Walker et al., 1960 ; Ewy et al., 1963; Tranquada et al., 1963). The purpose of this report is to record the fatal outcome in a patient who had ingested $50 \mathrm{mg}$. of phenformin in excess of the prescribed dose.

\section{CASE Report}

The patient, a 64-year-old housewife, had been known to suffer from maturity-onset diabetes for four years. She was treated with chlorpropamide for 18 months, and then with a 1,000-calorie diet (130 g. of carbohydrate) alone for three months. She remained more than a stone $(6.4 \mathrm{~kg}$.) above the standard weight for her height and was therefore started on phenformin in May 1964 in order to treat her mild hyperglycaemia and to facilitate weight reduction. The dose of phenformin was gradually increased and for five months before admission to hospital, on 10 June 1965, she was taking 25 mg. q.i.d. She had been in good health until 24 hours before admission, when the sudden onset of generalized abdominal pain was closely followed by vomiting of watery material. Her bowels were regular and a normal motion was passed in the interval between the onset of symptoms and admission. She denied any dyspeptic history or symptoms referable to the renal tract or cardiovascular system. The pain remained generalized and did not radiate from the abdomen. Twelve hours before the onset of her symptoms ( 36 hours before admission) she had mistakenly ingested two $25-\mathrm{mg}$. phenformin tablets in excess of her normal dose-that is, a total of $150 \mathrm{mg}$. in divided dosage in 12 hours.

On examination the patient, who lived in comfortable circumstances, was ill, pale, and obese and had acidotic respirations, but acetone could not be detected in the breath. She was moderately dehydrated. The rectal temperature was $88.2^{\circ} \mathrm{F}$. $\left(31.2^{\circ} \mathrm{C}\right.$.), she was orientated and examination of the peripheral nervous system showed no abnormality, though the plantar responses could not be elicited. Neither pupil reacted to light or to accommodation, and the left was larger than the right. The left fundus was normal and the right was obscured by cataract. Her chest was clinically and radiologically normal, and examination of the abdomen (including rectal investigation) showed no abnormality. The pulse was of poor volume, though regular at 100 per minute. No signs of cardiac failure were observed and the heart sounds were normal. Blood pressure was recordable at $96 / 60 \mathrm{~mm}$. $\mathrm{Hg}$ only after $7 \mathrm{mg}$. of metaraminol (Aramine) had been given intravenously.

The laboratory findings on admission were as follows: $\mathrm{Hb}$ 11.6 g. $/ 100 \mathrm{ml}$; W.B.C. $20,600 / \mathrm{cu}$. mm., differential normal ; E.S.R. $11 \mathrm{~mm}$. in the first hour. Urinalysis showed moderate proteinuria, no glycosuria, and only a trace of ketones to Acetest and negative ferric chloride reaction. There were no cells or casts in the urinary deposit. E.C.G. showed left ventricular hypertrophy and ischaemı; J waves were not present. Serum and electrolyte values (sodium, potassium, and chloride) were normal. Blood urea was $140 \mathrm{mg} . / 100 \mathrm{ml}$., falling to $84 \mathrm{mg} . / 100 \mathrm{ml}$. after rehydration. No salicylates were detected in the serum, and the values of serum transaminases (S.G.O.T., S.G.P.T.) and of serum amylase were normal. The plasma $\mathrm{CO}_{2}$ combining power was $5.8 \mathrm{mEq} / \mathrm{l}$. Blood sugar was $140 \mathrm{mg} . / 100 \mathrm{ml}$. and the serum lactic acid level was $240 \mathrm{mg} . / 100 \mathrm{ml}$. (26.7 mM./1.) five hours after admission.

Therapy was started with intravenous dextrose $5 \%$ and isotonic saline with added metaraminol and sodium bicarbonate. After 12 hours of such treatment her condition remained desperate. Despite giving $400 \mathrm{mEq}$ of sodium bicarbonate and $120 \mathrm{mg}$. of metaraminol in a total of $2,700 \mathrm{ml}$. of intravenous fluid she remained oliguric and grossly acidotic. At this point, 12 hours after starting treatment, the $\mathrm{CO}_{2}$ combining power was $4.9 \mathrm{mEq} / \mathrm{l}$. and the arterial $\mathrm{pH} 6.92 \mathrm{PCO}_{2}$ less than $30 \mathrm{~mm}$. and standard bicarbonates less than $6 \mathrm{mEq} / \mathrm{l}$.). The rectal temperature had risen to $94^{\circ} \mathrm{F}$. $\left(34.5^{\circ}\right.$ C.).

The patient's condition and blood pressure improved slightly after the infusion of $540 \mathrm{ml}$. of $10 \%$ dextrose in two hours, and $600 \mathrm{ml}$ of urine was passed in the second 12 hours, the blood pressure being 90 to $110 / 50$ to $60 \mathrm{~mm}$. Hg. Twenty-eight hours after admission she had a cardiac arrest. Immediate resuscitation was unsuccessful. Post-mortem examination failed to reveal any significant disease apart from thrombosed splenic vein.

Comment.-The only recognized factor which could contribute to the metabolic acidosis was the history of taking $50 \mathrm{mg}$. in excess of her usual $100 \mathrm{mg}$. daily of phenformin. She had no significant uraemia, salicylism, infection, or external cause for her acidosis and there was no preceding period of severe carbohydrate deprivation.

\section{Discussion}

Walker et al. (1960) discussed the action and side-effects of phenformin. It was suggested that associated acidosis was more likely to occur in juvenile diabetics on phenformin than in older diabetics. The degree of lactic acidosis found in our patient is an example of a rare occurrence in such an elderly mild diabetic. Dobson (1965) reported a case of attempted suicide by means of phenformin. A dose of $850 \mathrm{mg}$. was ingested but no acidosis was present. It was suggested that the gastrointestinal irritation may protect against the absorption of an overdose of this drug. This was not the position with our patient.

Huckabee (1961) described an ill-defined group of patients, not necessarily diabetic and not having any drug in common, who died in severe metabolic acidosis caused mainly by raised serum lactic acid. He believed the common factor in such cases was widespread tissue hypoxia of indeterminate cause. Such a vague description could of course fit our patient, irrespective of any drugs, but the distinct possibility exists that the trigger mechanism for the development of lactic acidosis was the modest overdose of phenformin. It is known that blood lactic acid levels may be expected to rise under the influence of phenformin in doses similar to those taken by our patient, but normally the rise is modest-for example, 4 to $31 \mathrm{mg} . / 100 \mathrm{ml}$. (Craig et al., 1960). The finding of $240 \mathrm{mg} . / 100 \mathrm{ml}$. in our patient is clearly of a different order of magnitude and difficult to explain. There was no clinical or post-mortem evidence of any process to cause hypoxia, which is a well-recognized cause of hyperlactacidaemia (Shepardson et al., 1962).

We gratefully thank Mr. T. Clark (City Analyst) and Professor S. C. Frazer and their staffs for the biochemical estimations so willingly carried out.

D. W. PROCTOR, M.B., CH.B., D.OBST.R.C.O.G.

J. M. STOWERS, M.A., M.D., F.R.C.P., F.R.C.P.ED. City Hospital, Aberdeen.

\section{REFERENCES}

Craig, J. W., Miller, M., Woodward, H., and Merik, E. (1960). Diabetes, 9. 186.

Dobson, H. L. (1965). Ibid., 14, 811.

Ewy, G. A., Pabico, R. C., Maher, J. F., and Mintz, D. H. (1963). Ann. intern. Med., S9, 878.

Huckabee, W. E. (1961). Amer. 7. Med., 30, 840.

Shepardson, C. R., Christopher, T. G., and Miller, M. (1962). F. Lab. clin. Med., 60, 1018.

Tranquada, R. E., Bernstein, S., and Martin, H. E. (1963). F. Amer. med. Ass., 184, 37.

Walker, R. S., Linton, A. L., and Thomson, W. S. T. (1960). Brit. med. 3 ., 2, 1567 